\title{
PSIKOTERAPI SUPORTIF PADA PENDERITA SKIZOFRENIA HEBEFRENIK
}

\author{
Anisa Fitriani \\ Fakultas Psikologi Universitas Islam Sultan Agung, Jl. Raya Kaligawe Km. 4 Semarang \\ Email: anisa.fitriani@unissula.ac.id
}

\begin{abstract}
Abstrak
Penelitian ini bertujuan untuk mengetahui efektivitas psikoterapi suportif pada penderita skizofrenia hebefrenik. Skizofrenia hebefrenik memiliki onset awal. Gejala-gejala dapat muncul dari usia remaja atau dewasa awal yang merupakan usia produktif untuk memulai mempersiapkan berbagai peran bagi masa depan. Prognosis seringkali lebih buruk dibandingkan dengan tipe lain jika tidak mendapatkan penanganan secara tepat.. Desain penelitian yang digunakan adalah eksperimen kasus tunggal dengan seorang subjek laki-laki yang didiagnosis mengalami skizofrenia hebefrenik dan telah mengalami kekambuhan sebanyak tiga kali. Data diperoleh dengan metode observasi, wawancara mendalam, tes psikologi, dan pengukuran kondisi subjek antara sebelum dan sesudah menjalani psikoterapi suportif. Hasil penelitian ini menunjukkan bahwa psikoterapi suportif dapat membantu penderita skizofrenia hebefrenik mempersiapkan diri untuk kembali menjalankan fungsinya dalam kehidupan sehari-hari. Terdapat perubahan dalam aspek pikiran, perasaan, dan perilaku yang lebih adaptif sehingga dapat menurunkan kemungkinan kekambuhan. Hasil penelitian ini juga menunjukkan bahwa psikoterapi suportif akan lebih efektif jika melibatkan peran keluarga secara aktif.
\end{abstract}

Kata Kunci: Psikoterapi suportif, skizofrenia, hebefrenik

\section{SUPPORTIVE PSYCHOTHERAPY TO HEBEFRENIC SCHIZOPHRENIA PATIENT}

\begin{abstract}
This study was aimed to determine the effectiveness of supportive psychotherapy in hebefrenic schizophrenic. Hebefrenic schizophrenia has an early onset. Symptoms can arise from adolescents or early adults and this is productive age to begin preparing various roles for the future. The prognosis is often worse than the other types if it does not get the right treatment. The design of this study was single case experiment with a male subject who was diagnosed with hebefrenic schizophrenia and had three times of recurrences. Data were obtained by observation, in-depth interviews, psychological tests, and measurement of subject conditions before and after supportive psychotherapy. The results of this study indicated that supportive psychotherapy can help hebefrenic schizophrenic prepare to carry out their functions in daily life. There were changes in aspects of the mind, feeling, and behavior became more adaptive so it reduced the possibility of recurrence. The results of this study also showed that supportive psychotherapy would be more effective if it actively involves the family's role.
\end{abstract}

Keywords: Supportive psychotherapy, schizophrenia, hebephrenic

\section{PENDAHULUAN}

Skizofrenia adalah gangguan mental berat dan perjalanan penyakitnya bersifat kronis atau bertahan dalam jangka waktu lama. Gangguan ini bisa muncul dari akhir masa remaja atau dewasa muda. Skizofrenia dapat terjadi karena adanya kelainan di dalam otak yang dapat berpengaruh pada proses persepsi, pikiran, emosi, gerakan dan perilaku sosial (Herdman, 2015). Pedoman Penggolongan dan Diagnosis Gangguan Jiwa III (PPDGJ III) mendefinisikan skizofrenia sebagai gangguan jiwa dengan distorsi yang khas dan fundamental pada pikiran dan persepsi, disertai munculnya afek tumpul atau tidak wajar. 
Lebih dari 21 juta orang di seluruh dunia menderita skizofrenia (WHO, 2016). Prevalensi gangguan jiwa berat, termasuk skizofrenia adalah 1,7 per 1.000 penduduk atau kurang lebih 400.000 orang. Angka tertinggi terdapat di DI Yogyakarta dan Aceh, sebanyak 2,7 per 1.000 penduduk (Riskesdas, 2013). Data lain menyebutkan bahwa jumlah di Indonesia mencapai 2,5 persen dari total penduduk dengan 80 persennya tidak mendapatkan pengobatan (Fiona, 2013).

Faktor penyebab skizofrenia bersifat multikompleks atau bisa berasal dari berbagai faktor yang saling berkaitan. Beberapa faktor tersebut diantaranya adalah ketidakseimbangan neurotransmiter tertentu di otak, proses perkembangan mental individu sejak masa anak-anak, tekanan psikososial yang bersifat berat dan terus-menerus. Skizofrenia juga merupakan penyakit yang bersifat progresif, cenderung berlangsung lama, terkadang kambuh, sehingga memberikan kesan bahwa penderita skizofrenia tidak bisa disembuhkan.

Diagnosis skizofrenia dapat ditegakkan jika gejala berlangsung selama minimal enam bulan dan setidaknya mencakup satu bulan dari gejala fase aktif. Skizofrenia terdiri dari beberapa tipe, yaitu paranoid, hebefrenik, katatonik, residual, dan tidak terkategori (Hendarsyah, 2016). Penelitian ini memfokuskan pada subjek skizofrenia dengan tipe hebefrenik. Skizofrenia tipe hebefrenik ini ditandai dengan adanya kemunduran perilaku dan memiliki onset awal jika dibandingkan dengan tipe lainnya. Individu yang mengalami skizofrenia hebefrenik akan menunjukkan perilaku aneh, kekanak-kanakan, bertingkah konyol, tertawa dangkal, asosiasi longgar, sedangkan delusi maupun halusinasi tidak tampak menonjol. Gejala lain yang bisa muncul adalah perilaku tanpa alasan dan tanpa tujuan, seperti berjalan tanpa tujuan. Terkadang sikap menarik diri juga muncul pada tipe ini. Beberapa juga menunjukkan gejala asosiasi longgar dan inkoherensi (Eddy, 2017).

Menurut Ibrahim (2011), tipe skizofrenia hebefrenik seringkali ditandai dengan adanya regresi yang dapat dilihat secara langsung, munculnya perilaku-perilaku primitif dan perilaku yang tidak teratur. Penderita skizofrenia hebefrenik seringkali terlihat aktif, tertawa tanpa alasan, menyeringai, akan tetapi perilakunya tidak konstruktif dan tampak tidak memiliki tujuan. Isi pikir dan arus pikirnya sangat terdisorganisasi, terlihat sangat menonjol dan kemampuan kontak dengan kenyataan cenderung buruk.

Onset awal pada skizofrenia hebefrenik biasanya ditunjukkan oleh munculnya gejala-gejala sejak usia remaja akhir yang seharusnya menjadi usia produktif bagi seseorang. Gejala-gejala yang muncul tentu menyebabkan berbagai dampak terutama bagi masa depan. Sangat disayangkan jika usia produktif yang seharusnya digunakan untuk belajar, memulai bekerja, mempersiapkan pernikahan, dan menjalankan peran lainnya ternyata terhambat karena gejala-gejala dari gangguan skizofrenia. Tipe hebefrenik menurut Eddy (2017) seringkali disebut sebagai tipe dengan prognosis yang buruk jika dibandingkan dengan tipe lainnya. Kondisi tersebut tentunya menjadi salah satu faktor dibutuhkannya penanganan yang tepat agar gejala tidak berkembang lebih buruk sehingga dapat meningkatkan prognosis.

Pasien akan sangat membutuhkan persiapan dan dukungan ketika kembali dari perawatan di Rumah Sakit Jiwa, terlebih di masyarakat kita masih sangat kental dengan stigma terhadap gangguan kejiwaan. Rasa malu, putus asa, tidak berdaya, dan perasaan-perasaan negatif lainnya dapat muncul jika tidak dibekali dengan pendampingan yang tepat. Melihat kondisi tersebut dibutuhkan suatu terapi yang bertujuan sebagai mendukung pasien agar dapat menjalani kehidupan sehari-hari dengan lebih adaptif, mengingat skizofrenia merupakan salah satu penyakit kronis. Artinya, gejala-gejala dari gangguan skizofrenia bisa jadi menetap dalam waktu lama walaupun intensitasnya semakin berkurang. 
Salah satu terapi yang sering digunakan untuk membantu individu dengan gangguan jiwa adalah supportive therapy atau terapi suportif. Terapi ini disusun berdasarkan pendekatan psikoanalisa. Corsini dan Wedding (2011) mengemukakan bahwa terapi dengan pendekatan psikoanalisa memiliki tujuan membawa klien secara menyeluruh untuk mengungkap sumber paling dasar dan terdalam dari permasalahan. Psikoanalisa juga digunakan sebagai cara untuk menjelaskan dan menangani perilaku manusia yang tidak mengikuti hukum logika yang ada, serta mengedepankan proses discovery and recovery.

Beberapa penelitian menunjukkan bahwa terapi suportif efektif untuk menangani berbagai permasalahan terkait skizofrenia. Penelitian yang dilakukan oleh Harkomah dkk (2018) menunjukkan bahwa terapi suportif merupakan salah satu terapi yang dapat berpengaruh pada keterampilan sosialisasi pada penderita skizofrenia. Penelitian lain oleh Pardede (2017) menunjukkan adanya pengaruh terapi suportif untuk mengurangi dorongan bunuh diri pada pasien skizofrenia, sedangkan penelitian yang dilakukan oleh Agustina (2017) menunjukkan bahwa terapi suportif dapat mengendalikan perilaku kekerasan pada pasien skizofrenia yang memiliki permasalahan terkait perilaku kekerasan.

Terapi suportif adalah bentuk psikoterapi yang dapat diterapkan secara individu maupun kelompok. Tujuan dari terapi ini adalah untuk melakukan evaluasi diri, melihat kembali cara menjalani hidup, eksplorasi berbagai pilihan yang ada, dan mengajukan pertanyaan pada diri sendiri terkait halhal yang diinginkan di masa depan (Palmer, 2011). Terapi suportif berupaya untuk membantu agar subjek dapat menjalankan fungsinya secara lebih efektif dengan cara memberikan dukungan secara personal. Terapis tidak meminta subjek berubah, akan tetapi terapis berperan sebagai pendamping. Terapis mendorong subjek untuk melakukan refleksi situasi terhadap kehidupan mereka di lingkungan.

Secara umum dapat disimpulkan bahwa terapi suportif memiliki tujuan untuk memperkuat fungsi psikologis subjek agar lebih sehat dan diharapkan muncul pola-pola perilaku yang lebih adaptif. Tujuan lain dari terapi suportif adalah mengurangi konflik intrapsikis yang seringkali berdampak pada munculnya gejala-gejala gangguan mental. Empati, dorongan dan dukungan merupakan aspek yang harus diberikan oleh terapis. Selain itu terapis juga perlu membangun hubungan saling percaya. Kepercayaan seorang klien pada terapis akan memberikan pengaruh dalam proses terapi (Mutiara, 2017).

Beberapa kegiatan dapat digunakan untuk memperkuat subjek saat menghadapi tekanan, seperti kegiatan mengekspresikan pikiran dan perasaan. Terapis juga akan membantu subjek agar mendapatkan pemahaman yang lebih baik mengenai situasi dan berbagai alternatif yang ada serta membantu meningkatkan ketahanan dan harga diri. Subjek akan didorong untuk mencapai harapanharapannya. Subjek juga dibantu untuk dapat membuat keputusan dan beradaptasi dengan lingkungan atau situasi-situasi yang mungkin mengecewakan dan tidak sesuai dengan harapan. Sebelum melaksanakan proses terapi, terapis akan melakukan asesmen mendalam terhadap latar belakang dan perilaku subjek. Hal ini menunjukkan bahwa hubungan saling percaya antara terapis dan subjek sangatlah penting. Terapi suportif ini dapat diberikan dalam jangka panjang maupun jangka pendek. Banyaknya sesi terapi yang dibutuhkan tergantung pada keadaan dan tingkat permasalahan (Mutiara, 2017).

Tahapan-tahapan terapi suportif berdasarkan pendapat Millon (1969) terdiri dari tiga tahapan inti. Ketiga prosedur tersebut dapat dilakukan secara terpisah, bersamaan, atau secara bertahap. Tahapan pertama adalah emotional ventilation. Tahapan ini merupakan elemen yang penting dari 
terapi suportif. Emotional ventilation menekankan bahwa ide dan dorongan tidak bisa dibuang dari pikiran seseorang dan dapat mengganggu kehidupan sehari-hari untuk meringankan tekanan ini, subjek perlu didorong untuk membagi pikirannya kepada terapis dan merasa bebas untuk mengekspresikan tekanan yang dihadapi. Subjek diyakinkan bahwa setiap orang mengalami ide atau tekanan yang mengganggu hidupnya, sehingga tidak perlu merasa ragu-ragu untuk menyampaikan pada terapis karena terapis akan memahami tanpa menyalahkan atau menghakimi. Subjek akan dilatih untuk mematahkan pandangan negatif terhadap diri sendiri. Fakta bahwa subjek diterima oleh terapis, walaupun menunjukkan kelemahannya, akan mendorongnya untuk berpikir ulang mengenai dirinya. Tujuan dari terapi ini terbatas untuk memulihkan keseimbangan diri tanpa mengganti perilaku premorbid dan kepribadiannya, sehingga subjek tidak dipaksa untuk membuka apa yang tidak diinginkan.

Tahap kedua dari terapi suportif adalah reassurance. Sesi reassurance dilakukan dengan cara yang lebih direktif dengan cara menunjukkan betapa pikiran dan perasaannya tidak beralasan dan betapa tidak adilnya subjek dalam menghukum dirinya. Subjek diyakinkan bahwa dirinya tidak sedang berada dalam kondisi yang buruk dan tidak memiliki harapan untuk menjadi lebih baik. Selalu ada orang-orang yang sadar dan memahami keadannya, sehingga pada sesi ini subjek dikuatkan dan dihibur agar tidak menghukum dirinya sendiri.

Tahapan terakhir disebut sebagai tahap persuation. Subjek diyakinkan bahwa dirinya memiliki sesuatu yang dapat dikembangkan. Peran terapis adalah melarang subjek untuk menahan dirinya dan mengajak untuk menolak asumsi dan kebiasaan irasional yang sebenarnya mengganggu kehidupannya selama ini. Sugesti konkrit dibuat untuk membantu subjek menentukan tujuan, mengusir kekhawatiran, menguasai berbagai pikiran, meningkatkan kepercayaan diri, penguasaan terhadap diri sendiri serta menghadapi berbagai situasi yang tidak menyenangkan dengan sikap objektif.

Tujuan dari terapi suportif di atas sesuai dengan kebutuhan subjek dalam penelitian ini yang merupakan penderita skizofrenia hebefrenik dengan onset awal. Gejala-gejala skizofrenia muncul saat subjek berusia 20 tahun. Subjek sudah pernah dirawat di Rumah Sakit Jiwa sebanyak tiga kali karena selalu mengalami kekambuhan setelah kembali pulang ke rumah.

Gejala-gejala muncul setelah subjek pulang dari merantau di lbu Kota karena kehilangan pekerjaan. Subjek sebetulnya sangat menyesal karena merasa gagal membahagiakan keluarga. Sejak saat itu subjek lebih banyak menghabiskan waktu bersama teman-teman yang sering melakukan ritualritual aneh. Subjek mulai mengikuti kegiatan mereka, seperti pergi ke kuburan, semedi, keluyuran tanpa tujuan, berbicara dan tertawa sendiri, makan berlebihan dan sulit tidur. Kelompok tersebut menjanjikan pengikutnya akan mendapatkan uang banyak tanpa harus bekerja. Subjek juga pernah menjual padi orang tuanya dan kemudian hasilnya dibagikan untuk orang lain. Subjek sering mengatakan bahwa sebentar lagi subjek akan mendapatkan uang banyak dan bisa membahagiakan orang tua.

Subjek sering menunjukkan perilaku aneh, seperti sholat menghadap ke Timur, sulit tidur, tertawa dan berbicara sendiri, mengurung diri, keluyuran, rawat diri kurang, dan tidak mau mandi selama beberapa hari. Selanjutnya subjek sering menunjukkan perilaku marah, mudah tersinggung, mengancam akan bunuh diri dan membunuh orang lain dengan senjata tajam, merusak alat-alat rumah tangga, memecah kaca rumah tetangga. Subjek juga beberapa kali mengamuk di warung tetangga agar diberikan rokok secara gratis. Subjek juga semakin terlarut dengan hal-hal yang berbau mistis, seperti 
melafalkan berbagai mantra, merasa rohnya bisa terbang, dan berbagai bentuk halusinasi mulai muncul.

Sebelum merantau, subjek dikenal sebagai anak yang baik, sering membantu orang tua bekerja di sawah, mencari rumput, kayu bakar dan rajin sholat berjamaah di masjid, bahkan terkadang diminta untuk mengumandangkan adzan. Subjek juga bersedia membantu keuangan keluarga dengan bekerja di mana saja, seperti di bengkel dan menjadi tukang ojek. Uang yang dihasilkan juga sering diberikan pada orang tua untuk membantu menyokong kehidupan keluarga sehari-hari. Namun saat bekerja di tempat perantauan, subjek terbawa oleh perilaku teman-temannya yang suka merokok, minum minuman keras, dan beberapa kali melakukan hubungan seksual dengan lawan jenis maupun dengan waria.

Selama ini kekambuhan subjek dipicu oleh tidak adanya pendampingan saat sudah kembali ke rumah. Subjek mengalami kebingungan akan menjalani aktivitas apa dan tidak memiliki tujuan yang pasti. Selain itu keluarga juga kurang memberikan dukungan karena orang tua sudah merasa lelah dengan perilaku subjek selama ini, bahkan ibu subjek sempat berpikir akan lebih baik jika subjek disuntik mati saja. Keluarga juga sering merasa kebingungan harus melakukan apa untuk menghadapi subjek. Keluarga juga sering menunjukkan rasa malu pada orang-orang di lingkungan sekitar atas perilaku subjek. Masyarakat setempat belum bisa memahami bahwa perilaku aneh subjek merupakan gejala yang muncul dari gangguan skizofrenia. Selain itu pemahaman tentang penanganan gangguan jiwa juga masih menjadi hal asing sehingga subjek juga pendapatkan penanganan yang kurang cepat.

Sesuai dengan tujuan dari masing-masing tahapan terapi suportif, penelitian ini diberikan dengan tujuan agar subjek lebih memahami kondisi dirinya, memberikan dukungan dan penguatan, serta mempersiapkan subjek untuk kembali ke lingkungan, mengenali potensi dan menetapkan tujuan, dan mengarahkan agar subjek mampu memilih perilaku yang lebih adaptif agar tidak mengalami kekambuhan.

\section{METODE}

Penelitian ini menggunakan desain eksperimen kasus tunggal (single-case experimental design), yaitu sebuah desain penelitian yang bertujuan untuk mengevaluasi efek suatu perlakuan atau intervensi kasus tunggal. Kasus tunggal yang dimaksud dapat berupa beberapa subjek dalam satu kelompok atau kasus tunggal pada satu orang subjek. Desain ini dianggap sesuai untuk melakukan penelitian terkait manusia, terutama saat perilaku yang diukur tidak bisa diambil rata-ratanya (Latipun, 2008).

Subjek dalam penelitian ini adalah seorang laki-laki berusia 22 tahun yang didiagnosis menderita skizofrenia tipe hebefrenik. Pengukuran mengenai kondisi subjek dilakukan sebelum subjek menjalani terapi (baseline) dan setelah menjalani terapi. Pengukuran tersebut bertujuan untuk melihat perubahan-perubahan yang terjadi sesuai dengan tujuan dari masing-masing tahapan terapi suportif. Pelaksanaan terapi suportif dimulai setelah subjek menunjukkan sikap kooperatif, gejala-gejala skizofrenia sudah berkurang dan siap untuk kembali ke lingkungan sosial setelah proses perawatan di Rumah Sakit Jiwa.

Data dalam penelitian ini diperoleh dengan metode observasi, wawancara, dan tes psikologi. Wawancara menjadi metode utama untuk menggali data secara mendalam. Wawancara dilaksanakan dengan dua cara. Pertama adalah autoanamnesa, yaitu secara langsung dengan subjek. Tujuannya 
untuk mengetahui secara langsung dan mendalam semua data terkait subjek, seperti riwayat kehidupan subjek dari masa anak-anak, apa yang dialami dan dirasakan oleh subjek, termasuk hal-hal yang berkaitan dengan gangguan. Kedua adalah wawancara alloanamnesa, yaitu wawancara yang dilakukan dengan orang-orang terdekat subjek sebagai pelengkap dan sumber informasi dari sudut pandang yang berbeda.

Metode observasi digunakan sebagai metode yang dapat mendukung data-data lainnya, misalnya data yang diperoleh dari hasil wawancara. Observasi meliputi observasi fisik, kegiatan seharihari subjek, lingkungan sekitar, dan berbagai perilaku saat wawancara atau tes psikologi. Tes psikologi yang adalah DAP, BAUM, HTP, dan Wartegg dengan untuk mengungkap hal-hal yang ada di alam bawah sadar dan mengetahui gambaran kepribadian subjek.

Data yang diperoleh akan dianalisis secara deskripsi kualitatif dengan membandingkan kondisi subjek antara sebelum menjalani terapi suportif dan setelah menjalani terapi suportif. Selain itu juga akan dilihat kesesuaiannya dengan tujuan dari masing-masing tahapan terapi suportif.

\section{HASIL DAN PEMBAHASAN}

Terapi suportif dalam penelitian ini dilaksanakan sebanyak lima kali pertemuan. Proses pendekatan atau building rapport menjadi hal yang sangat penting mengingat salah satu aspek yang harus dipenuhi dalam kelancaran terapi ini adalah adanya hubungan saling percaya antara subjek dengan terapis. Hubungan saling percaya antara subjek dan terapis sudah dibangun sejak proses asesmen, seperti saat wawancara awal dan saat pemberian tes psikologi.

Tidak munculnya sikap menarik diri sebagai gejala dari skizofrenia hebefrenik juga menjadi salah satu faktor pendukung. Gejala tersebut berdampak pada sikap subjek yang tidak menghindari orang lain, mampu bersahabat tanpa kecurigaan dan tidak adanya gejala yang mengarah pada sikap paranoid. Kondisi tersebut menjadi salah satu faktor pendukung kesesuaian terapi suportif yang diberikan pada subjek.

Terapi ini terdiri dari tiga tahapan dan masing-masing memiliki tujuan yang berbeda-beda, yaitu emotional ventilation, reassurance, dan persuation. Fase emotional ventilation menjadi sarana bagi subjek untuk mengungkapkan pikiran dan perasaan yang selama ini tidak bisa diekspresikan dengan tepat dan menjadi tekanan dalam kehidupan subjek. Subjek memiliki berbagai kekecewaan sebelum menderita skizofrenia, seperti kekecewaan pada diri sendiri dan kekecewaan pada sosok orang tua yang dianggap tidak memberikan banyak perhatian sejak subjek kecil. Subjek mampu mengungkapkan kejadian demi kejadian terkait dengan dirinya sendiri dan keluarga. Pada sesi ini subjek menangis karena merasa selama ini tidak ada yang orang yang peduli padanya, tidak pernah ada orang yang menanyakan apa yang sebenarnya sedang ia hadapi.

Tahap kedua adalah reassurance. Sesi ini dilaksanakan secara lebih direktif oleh terapis pada subjek. Terapis mengarahkan subjek untuk bersama-sama mencari berbagai alternatif lain yang lebih positif terkait dengan perasaan, pikiran, dan perilaku subjek. Terapis memiliki tugas untuk membimbing agar subjek memahami bahwa masih ada harapan di masa depan. Subjek memiliki keinginan untuk bekerja akan tetapi selama ini terhambat karena sering mengalami kebingungan dan hanya terpaku pada pertanyaan-pertanyaan tentang apa yang seharusnya subjek lakukan. Kondisi tersebut membuat subjek lebih memilih untuk berdiam diri, tetap kebingungan, kesepian, sampai akhirnya gejala-gejala skizofrenia muncul kembali dan subjek harus kembali dirawat di Rumah Sakit 
Jiwa. Subjek mulai mengenali pola kekambuhan pada dirinya dan belajar untuk mengidentifikasi berbagai faktor yang menyebabkan.

Tahap selanjutnya adalah persuation. Subjek diajak untuk melihat potensi-potensi yang dapat dikembangkan pada dirinya. Terapis memberikan penguatan agar subjek memahami berbagai pemikiran irasional dan berbagai perilaku yang selama ini menjadi penghambat dalam kehidupannya. Sugesti konkrit diberikan pada subjek untuk menentukan tujuan dan hal-hal yang selanjutnya akan dilakukan agar subjek tidak mengalami kekambuhan serta dapat berfungsi dengan lebih adaptif dalam kehidupan sehari-hari, baik di lingkungan keluarga, lingkungan sosial, dan lingkungan pekerjaan.

Berikut ini adalah hasil penilaian kondisi subjek dari sebelum dan sesudah menjalani terapi suportif.

Tabel 1. Kondisi Sebelum dan Sesudah Menjalani Terapi Suportif

\begin{tabular}{|c|c|}
\hline Sebelum Menjalani Terapi Suportif & Setelah Menjalani Terapi Suportif \\
\hline $\begin{array}{l}\text { Subjek tidak pernah memiliki } \\
\text { kesempatan untuk mengekspresikan } \\
\text { secara bebas berbagai perasaan dan } \\
\text { pikiran yang selama ini dipendam. } \\
\text { Subjek merasa tidak ada orang yang bisa } \\
\text { diajak berbicara mengenai } \\
\text { permasalahannya. }\end{array}$ & $\begin{array}{l}\text { Subjek memiliki kesempatan untuk } \\
\text { mengungkapkan berbagai perasaan dan } \\
\text { pikiran yang selama ini menjadi tekanan } \\
\text { dalam kehidupannya. } \\
\text { Subjek menyadari bahwa ada orang } \\
\text { yang bisa menunjukkan sikap peduli } \\
\text { pada kondisinya saat ini. } \\
\text { Subjek mendapatkan perasaan lega dan } \\
\text { ringan karena telah menangis dan } \\
\text { melakukan katarsis. }\end{array}$ \\
\hline $\begin{array}{l}\text { Subjek tidak pernah berfikir tentang } \\
\text { pola-pola perilaku yang menjadi faktor } \\
\text { penyebab kekambuhannya selama ini. }\end{array}$ & $\begin{array}{l}\text { Subjek mendapatkan pemahaman } \\
\text { bahwa kekambuhan gejala skizofrenia } \\
\text { dapat disebabkan oleh berbagai faktor } \\
\text { eksternal maupu internal yang selama } \\
\text { ini tidak pernah subjek pikirkan. } \\
\text { Subjek mampu menjelaskan pola-pola } \\
\text { tingkah laku yang menyebabkan } \\
\text { kekambuhannya. }\end{array}$ \\
\hline $\begin{array}{l}\text { Subjek menganggap bahwa } \\
\text { membahagiakan orang tua hanya bisa } \\
\text { dilakukan dengan uang, sehingga ia } \\
\text { sering bergabung dengan orang-orang } \\
\text { yang menjalankan berbagai ritual di } \\
\text { kuburan untuk mendapatkan uang } \\
\text { secara cepat. }\end{array}$ & $\begin{array}{l}\text { Subjek mendapat pemahaman bahwa } \\
\text { membuat orang tua senang tidak hanya } \\
\text { dengan uang saja. } \\
\text { Subjek juga menyetujui bahwa ritual- } \\
\text { ritual yang sering dilakukan adalah salah } \\
\text { satu faktor penyebab kekambuhannya. } \\
\text { Subjek mampu menjelaskan bahwa } \\
\text { selama ini ia sama sekali tidak } \\
\text { mendapatkan kekayaan dari ritual-ritual } \\
\text { tersebut, begitu juga dengan teman- } \\
\text { temannya yang sudah lebih lama } \\
\text { mengikuti kelompok tersebut. "Jika } \\
\text { dengan bersemedidikuburan seseorang } \\
\text { dapat kaya, maka yang akan kaya } \\
\text { terlebih dahulu adalah juru kunci } \\
\text { kuburan". }\end{array}$ \\
\hline
\end{tabular}




\begin{tabular}{ll}
\hline & Subjek mampu memberikan kesimpulan \\
& bahwa uang hanya bisa didapatkan \\
& dengan bekerja keras. \\
\hline $\begin{array}{l}\text { Subjek mengenali potensi yang ada } \\
\text { dalam dirinya, akan tetapi sering merasa }\end{array}$ & Setelah mengenali potensi yang ada di \\
ragu untuk menerima pekerjaan dari & dalam dirinya, seperti keterampilan \\
tetangga. & merbengkelan dan pertanian, subjek \\
& menerima tawaran tetangga untuk \\
& bekerja di bengkel dan tidak hanya \\
& bermalas-malasan di rumah. \\
& Subjek juga bersedia untuk membantu \\
& orang tua bekerja di ladang dan sudah \\
disepakati akan mendapat bagian utama & menyirami tanaman dan membersihkan \\
& rumput. \\
\hline & Subjek memiliki buku catatan kecil dari \\
terapis yang dapat digunakan untuk \\
menuliskan apapun, termasuk hal-hal \\
yang sudah didapatkan selama proses \\
terapi. \\
Subjek juga menuliskan apa saja tujuan \\
ke depan, hal-hal yang harus dilakukan \\
dan yang harus ditinggalkan.
\end{tabular}

Berdasarkan data di atas, dapat dilihat perbandingan kondisi subjek antara sebelum dan sesudah menjalani terapi. Perubahan yang terjadi meliputi perubahan pada pikiran, perasaan dan perilaku subjek.

Kesempatan untuk mengekspresikan pikiran dan perasaan dalam salah satu tahap terapi suportif dapat menjadi media katartis bagi subjek. Menurut Wahyuningsih (2017) penyaluran emosi yang ditekan akan terjadi dalam proses katarsis. Berbagai luapan emosi yang ditekan terkadang disebabkan oleh peristiwa traumatik di masa lalu yang belum terselesaikan dengan baik. Teori tentang katarsis ini berasal dari lingkungan psikoanalisis yang dikembangkan oleh Sigmund Freud. Teori ini menyatakan bahwa terapis harus memberi kesempatan pada individu untuk melakukan katarsis, bahkan katarsis yang dilakukan dengan cara yang tepat dapat mengurangi kecenderungan seseorang untuk melakukan berbagai tindakan yang mengarah pada agresivitas terhadap orang lain. Katarsis dapat membantu individu untuk meringankan beban yang selama ini ditekan dan tidak dapat diekspresikan dengan tepat.

Subjek mendapatkan kesempatan untuk meluapkan berbagai perasaan dan pikiran yang selama ini ditekan, termasuk kekecewaan pada diri sendiri dan orang lain, kesedihan, rasa sepi, dan berbagai peristiwa dari masa kecil yang masih menggangu pikirannya sampai saat ini. Fase ini memberikan perasaan lebih ringan dan lega karena tumpukan emosi yang selama ini dipendam akhirnya mendapat media untuk disalurkan. Setelah melakukan katarsis, subjek juga lebih memahami kondisinya saat. Hal ini sangat dibutuhkan untuk melanjutkan tahapan berikutnya. Subjek juga menjadi lebih percaya pada terapis sehingga hubungan terapeutik antara terapis dan subjek dapat terjalin dengan lebih baik. Menurut Mutiara (2017) kondisi saling percaya memang menjadi salah satu aspek yang sangat ditekankan pada pelaksanaan terapi suportif ini. 
Proses katarsis yang terdapat pada tahapan emotional ventilation pada terapi suportif dapat berkedudukan sebagai gerbang pembuka untuk tahapan-tahapan berikutnya. Tahapan reassurance lebih menekankan pada perubahan pada diri subjek dan proses meyakinkan bahwa subjek masih memiliki harapan. Seperti yang dikemukakan oleh Millon (1969) tentang tahapan reassurance, subjek akan diberikan penguatan dan dihibur agar tidak menghukum dirinya sendiri. Dalam penelitian ini, subjek juga diarahkan untuk mencari berbagai alternatif pikiran yang lebih adaptif. Tahap selanjutnya subjek diberikan sugesti konkrit untuk membantunya menentukan tujuan, mengurangi kekhawatiran, meningkatkan tanggung jawab, kepercayaan diri dan penguasaan terhadap diri sendiri untuk menghadapi berbagai kemungkinan yang akan terjadi.

Setelah menjalani terapi, subjek sering menuliskan berbagai hal di buku catatan yang diberikan oleh terapis. Subjek mendapatkan sarana yang lebih adaptif dalam mengekspresikan perasaan dan pikiran. Proses menulis tersebut juga dapat menjadi media bagi subjek untuk melakukan katarsis agar emosi negatif yang bisa datang kapan saja dapat tersalurkan dengan cara yang lebih baik. Beberapa tulisan tentang rencana ke depan dan kegiatan sehari-hari yang akan dilakukan juga ditempelkan di dinding kamar. Subjek merasa cara tersebut juga akan efektif untuk menjadi pengingat.

Pelaksanaan terapi suportif yang diberikan pada subjek ternyata tidak bisa dipisahkan dari intervensi kepada pihak keluarga. Subjek menyimpan berbagai kekecewaan dan berbagai perasaan yang belum tersampaikan. Berdasarkan data yang diperoleh dari keluarga, selama ini komunikasi antar anggota keluarga memang tidak berjalan dengan baik, terutama komunikasi antara orang tua dengan subjek setelah menderita skizofrenia.

Terapi suportif yang diberikan disertai dengan psikoedukasi pada orang tua terkait dengan pemahaman pada kondisi subjek dan beberapa hal yang sebaiknya dilakukan untuk memberikan dukungan pada subjek. Keluarga diberikan pemahaman bahwa proses perawatan skizofrenia sangat dipengaruhi oleh peran keluarga dan lingkungan sekitar, termasuk dukungan untuk meminum obat secara teratur. Selama ini keluarga kurang memberikan perhatian pada rutinitas meminum obat yang wajib dijalani oleh subjek agar tidak mengalami kekambuhan. Bahkan beberapa kali subjek sengaja tidak minum obat sebelum diingatkan oleh orang tua. Subjek mencoba untuk mencari perhatian dari orang tua yang menurutnya tidak ia dapatkan.

Kurangnya dukungan dari keluarga juga disebabkan oleh beberapa faktor, seperti kurangnya pemahaman terhadap kondisi subjek, masih berkembangnya stigma tentang gangguan jiwa, dan rasa malu pada lingkungan sekitar. Kekambuhan gangguan skizofrenia sehingga harus berulang kali dirawat di Rumah Sakit dapat disebabkan karena kurangnya dukungan dan pendampingan perawatan berkelanjutan yang dilakukan di lingkungan keluarga (Pardede, 2017). Hal ini sejalan dengan apa yang dikemukakan oleh Badriyah (2011), beberapa penelitian menunjukkan bahwa keterlibatan sanak keluarga dalam proses terapi skizofrenia adalah langkah yang tepat untuk menurunkan kekambuhan. Kecepatan kekambuhan tersebut dapat diturunkan hingga $20 \%$.

\section{KESIMPULAN DAN SARAN}

Berdasarkan penelitian yang telah dilaksanakan dapat disimpulkan bahwa terapi suportif dapat digunakan untuk membantu individu yang mengalami gangguan skizofrenia hebefrenik yang pada umumnya memiliki onset di masa remaja akhir atau dewasa awal. Usia tersebut merupakan usia produktif dengan berbagai peran yang seharusnya mulai dijalankan. Terapi suportif dapat mendorong 
subjek mengalami berbagai perubahan pikiran, perasaan, dan perilaku. Terapi suportif juga dapat membantu subjek memahami pola-pola perilaku yang dapat menyebabkan kekambuhan.

Keterlibatan keluarga dalam proses terapi juga menjadi faktor yang sangat penting, mengingat keluarga adalah orang-orang terdekat yang memberikan pendampingan. Maka dari itu dibutuhkan penelitian lanjutan yang tidak hanya terfokus pada penanganan penderita skizofrenia, tetapi juga pada pihak keluarga.

\section{DAFTAR PUSTAKA}

Agustina. (2017). Penerapan terapi suportif pada pasien skizofrenia dengan masalah keperawatan perilaku kekerasan di ruang kenari rumah sakit jiwa menur surabaya. Tesis. Universitas Universitas Nahdlatul Ulama Surabaya. http://digilib.unusa.ac.id/data_pustaka14617.html diakses pada tanggal 1 April 2017.

Departemen Kesehatan Republik Indonesia. (1993). Pedoman Penggolongan dan Diagnosis Gangguan Jiwa di Indonesia III. Jakarta: Departemen Kesehatan.

Eddy, F.N.E., Septa, T., Angraini, D.I. (2017). Diagnosis dan tatalaksana skizofrenia hebefrenik putus obat dengan Logorrhea. J Medula Unila. Vol 7 No. 3 hal. 17-21.

Fiona K. (2013). Pengaruh dukungan sosial terhadap kualitas hidup penderita skizofrenia. Jurnal Psikologi Kepribadian dan Sosial Universitas Airlangga. Vol. 2 (3). hal. 106-13.

Harkoma, I., Arif Y., Basmanelly. (2018). pengaruh terapi social skills training (sst) dan terapi suportif terhadap keterampilan sosialisasi pada klien skizofrenia di rumah sakit jiwa daerah provinsi jambi. Indones. J.Heal. Sci., Vol. 2, no.1, hal.61-65

Hendarsyah F. (2016) Diagnosis dan tatalaksana skizofrenia paranoid dengan gejala-gejala positif dan negatif. J Medula Unila. 4(3):58-63.

Herdman, T. H. (2015). NANDA International Nursing Diagnoses: Definitions \& Classification, 2015 2017: Oxford: Wiley-Blackwell

Ibrahim, A. S. (2011). Skizofrenia Spliting Personality. Tangerang: Jelajah Nusa

Millon, T. (1969). Modern Psychopathology. Ontario: W.B.Saunders Company

Mutiara. (2017). Penerapan Terapi Suportif untuk Meningkatkan Manajemen Emosi Negatif pada Individu yang Memiliki Pasangan Skizofrenia. Jurnal Muara IImu Sosial, Humaniora, dan Seni. Vol. 1, No. 1, April. Hal. 105-115.

Palmer, Stephen. (2011). Introduction To Counselling and Psychoterapy: The Essential Guide (Konseling dan Psikoterapi), diterjemahkan oleh Sage Publication Ltd. Yogyakarta: Bandung.

Pardede, S. (2017). Penerapan terapi suportif dengan teknik bimbingan untuk mengurangi dorongan bunuh diri pada pasien skizofrenia. Teraputik Jurnal Bimbingan dan Konseling. Vol. 1 No. 1. Hal. 89-96. 
Pilpala, Triharim.K.S. (2013). terapi supportif dan psikoedukasi untuk meningkatkan pemahaman diri pada penderita skizofrenia paranoid. Procedia Studi Kasus dan Intervensi Psikologi, Volume I (I), 46-51.

Riskesdas. (2013). Riset Kesehatan Dasar. http://www.depkes.go.id. Diakses pada tanggal 1 April 2017.

Wahyuningsih, S. (2017). Teori katarsis dan perubahan sosial. Jurnal Komunikasi. Vol. XI, No. 1. Hal. 3952. 